\title{
Reworked Precambrian metamorphic basement of the Lhasa terrane, southern Tibet: \\ Zircon/Titanite U-Pb geochronology, Hf isotope and Geochemistry
}

\author{
X. $\mathrm{DONG}^{1}$, Z.M. ZHANG ${ }^{1}$, Y.L. NIU ${ }^{2}$
}

${ }^{1}$ Institute of Geology, Chinese Academy of Geological Sciences, Beijing, 100037, China (*correspondence: dongxin5811935@163.com)

2 Department of Earth Sciences, Durham University, Durham, DH1 3LE, UK

As the main tectonic component of the Tibetan Plateau, the Lhasa terrane has been considered to be composed dominantly of Paleozoic to Mesozoic strata, Mesozoic and Cenozoic igneous rocks and Precambrian basement [1]. Due to the paucity of exposure, the formation and evolution of the Precambrian basement of the Lhasa terrane remain poorly known. Here we report zircon and titanite in situ U-Pb ages, bulk-rock geochemical and zircon Hf isotopic data on the orthogneisses from the Dongjiu area of the southern Lhasa subterrane (SLT), southern Tibet. Geochemical data suggest that the protoliths of the biotite-amphibole gneiss and biotite gneiss are granodiorite and granite, respectively. Inherited magmatic zircon cores from these orthogneisses give protolith crystalline ages of 1520-1506 Ma, whereas the overgrown zircon rims give metamorphic ages of 605-590 Ma. The Mesoproterozoic granitic rocks have bulk-rock $\varepsilon_{\mathrm{Nd}}(\mathrm{t})$ values of -3.6 to +0.1 and zircon core $\varepsilon_{\mathrm{Hf}}(\mathrm{t})$ values of -4.5 to +2.6 , which give similar $\mathrm{T}_{\mathrm{DM} 2}$ ages of $2.35-2.05 \mathrm{Ga}$ and 2.54-2.10 Ga respectively, suggesting their derivation from partial melting of Paleoproterozoic crustal material. The granitic rocks are also local provenance for the Mesoproterozoic detrital zircons in the Paleozoic strata in the Lhasa terrane. Titanite in situ $\mathrm{U}-\mathrm{Pb}$ ages further indicate that the Dongjiu orthogneiss experienced more recent metamorphism at $\sim 26 \mathrm{Ma}$. The mineral assemblage and thermobarometry calculations indicate that the Oligocene metamorphism occurred under medium-pressure (MP) amphibolite-facies conditions (5.4-7.2 kbar, 691-765 ${ }^{\circ} \mathrm{C}$ ). We propose that the Dongjiu gneisses represent the Precambrian metamorphic basement of the Lhasa terrane, but have been intensively reworked by metamorphism in the SLT in response to the continued India-Asia convergence since the collision.

[1] Yin and Harrison (2000) Annu. Rev. Earth Planet. Sci. 28, 211-280. 